\author{
${ }^{\circ}$ 相田美喜（筑波大）・伊藤一幸（東北農研）・池田浩明・原田值國・ \\ 石井康雄 (農環研) ・ 臼井健二（筑波大）
}

水田除草剤のベンスルフロンメチル(BSM)が、絶滅危惧種とされる水生シダのサンショウモ、オオアカウキク サ、デンジソウおよびミズニラの生育に及ぼす影響を野外試験により検討した。また、サンショウモとオオア カウキクサの現生育地における出現状況と BSM 濃度の消長を調查するとともに、現生育地において想定される 低濃度域の BSMに対するサンショウモとオオアカウキクサの感受性を室内試験により検討した。

\title{
〈材料・方法〉
}

2002 年 5 月 8 日、谷和原水田下層土を $1 / 5000 \mathrm{a}$ ポットに $1.5 \mathrm{~kg}$ ずつ詰め、 $\mathrm{N}: \mathrm{P}: \mathrm{K}=8: 16: 8 \mathrm{~kg} / 10 \mathrm{a}$ となるよう施 肥し、代かきを行った。サンショウモ（茨城県阿見町産）は4 6 葉期の胞子体を 20 個、オオアカウキクサ (茨 城県阿見町産）は葉面積が約 $1.5 \mathrm{~cm}^{2}$ の胞子体を 3 個、デンジソウ（長野県坂城町産）は先端から約 $10 \mathrm{~cm}$ の長さ の匍匐茎を 1 本、ミズニラ（茨城県土浦市産）は3〜5葉期の個体を 3 株、それぞれ移植した。水深を 7 $8 \mathrm{~cm}$ と し、BSM 剤 (10\%粉剤) を処理した。処理量は、サンショウモとオオアカウキクサについて 0、0.5、1.5、5、15、 $50 \mathrm{~g}$ a.i/ha とし、デンジソウとミズニラについて 0、0.75、2.5、7.5、25、75g a.i.ha とした。試験期間中は上部から 潅水し、漏水操作は行わなかった。処理 20 日後に植物体を回収し、 $80^{\circ} \mathrm{C} ゙$ 特間乾燥させ乾物重を測定した。 また、代かきまで同様に行つたポット（無栽培区）に、1.5、15、150g a.i/ha の BSMを処理した。1、3、7、14、 21 日後に表層水を採取し、ELISA キット [(株) ヤトロン、大塚化学 (株) ] を用いて BSM 濃度を測定した。

2002 年 5 8 月、茨城県阿見町廻戸地区および霞ヶ浦町手野地区のハス田とハス田水路において $\operatorname{lm} \times 1 \mathrm{~m}$ 方形 区における浮葉植物とハスの被度を目視により測定した。また、周辺の水田において使用された BSM の流入が 考えられる同調査地において定期的に試料水を採取し、ELISAキットを用いて BSM 濃度を測定した。

BSM（原体）濃度が $0 、 0.04 、 0.1 、 0.4 \mu \mathrm{g} /$ となるよう調整した $1 / 4$ 強度の Hutner 水耕液を $6 \times 6 \times 10 \mathrm{~cm}$ のプラン トボックスに $50 \mathrm{ml}$ ずつ加え、サンショウモ（3 胞子体）とオオアカウキクサ（1 胞子体）を移植した。人工気 象室（明期 $14 \mathrm{~h}, 25^{\circ} \mathrm{C} / 15^{\circ} \mathrm{C}, 280 \mu \mathrm{Em}^{-2} \mathrm{~s}^{-1}$ ) 内で 20 日間生育させ、植物体を回収し 乾物重を測定した。

\section{<結果 >}

無栽培区における水中 BSM 濃度は、処理後約 20 日間で処理直後の水中濃度（理論值）の $1 / 10$ 程度に減少し た（図1）。4種の栽培区において、サンショウモは $0.5 \mathrm{~g}$ a.i.ha 処理区から生育抑制が見られ (図2 )、50g a.i.ha 処理区では完全に枯死する個体がほとんどだった。また、サンショウモは $0.5 \mathrm{~g}$ a.i.ha 処理区において側芽の伸長 が盛んであった。オオアカウキクサは $1.5 \mathrm{~g}$ a.i.ha 以上の処理区において顕著に生育抑制が見られた。デンジソウ は $0.75 \mathrm{~g}$ a.i./ha 処理区から著しい生育抑制が見られた。ミズニラは $7.5 \mathrm{~g}$ a.i.ha 以下の処理区において生育促進の傾 向を示した。また、高濃度処理区における生育抑制の程度は他の 3 種と比較して小さかった。

ハス田とハス田水路においてサンショウモとオオアカウキクサの出現が確認され、両種以外にはウキクサと コウキクサが優占していた (図3 )。サンショウモは6月下旬以降に出現した。ハス田における BSM 濃度は非常 に低かったが、ハス田水路においては 5 月〜 月月にかけて 0.1〜 1 $\mu$ g/ 程度の BSM が検出された（図3 )。

サンショウモは水耕による全ての処理区において無処理区との有意差がみられ、オオアカウキクサは $0.4 \mu \mathrm{g} /$ 処理区において有意差がみられた（図4)。サンショウモはBSMに対する感受性が非常に高いことが示された。

Aida,M.,K.Itoh,H.Ikeda,N.Harada,Y.Ishii and K.Usui : Growth response to bensulfuron'methyl in some aquatic fern species. 


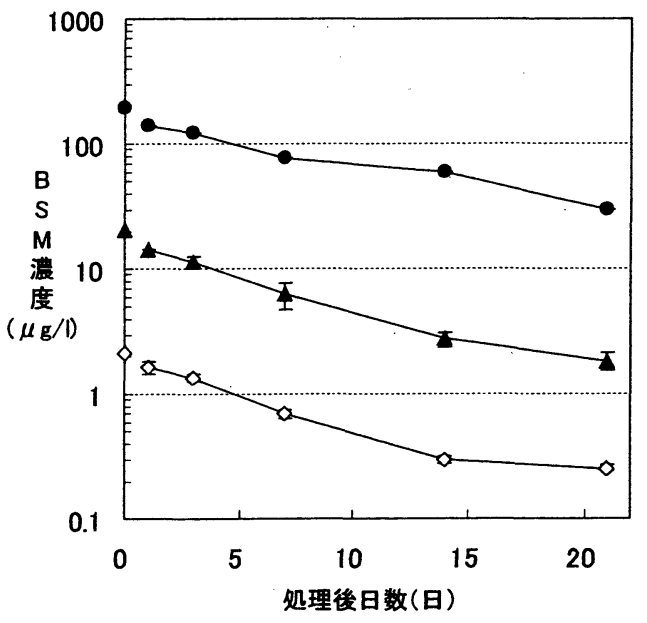

$\checkmark 1.5 \mathrm{~g}$ a.i./ha 処理 $-15 \mathrm{~g}$ a.i./ha 処理 - 150g a.i./ha処理

図1 無栽培区における水中BSM 濃度の消長 (平均値 \pm S.E.)

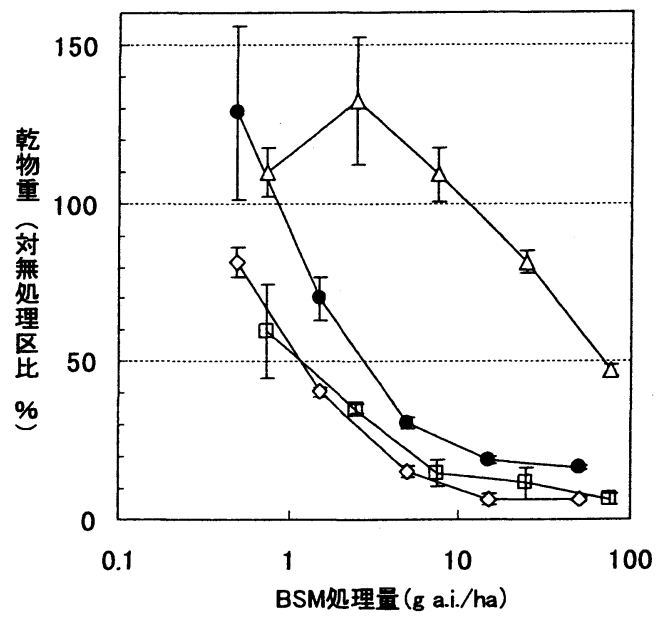

๙ーサンショウモ モーデンジソウ

一ーオオアカウキクサ

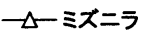

図2 BSM剂処理(土耕)20日後における 水生シダ4種の乾物重(平均値士S.E.)

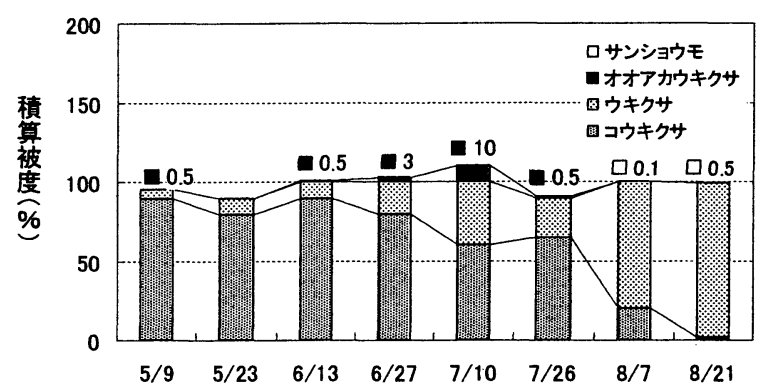

調查月日

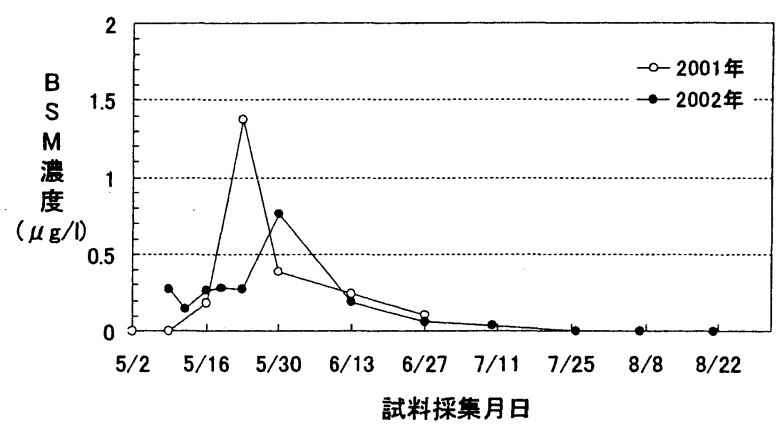

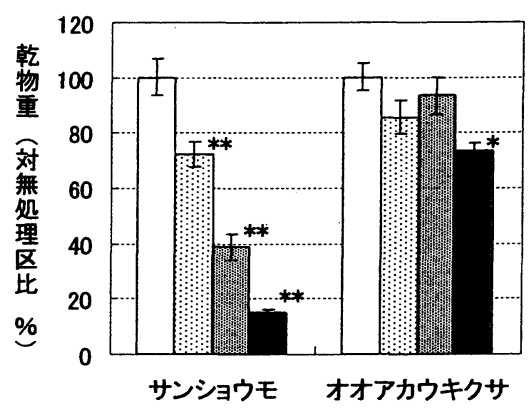

口無処理 $\boxminus 0.04 \mu \mathrm{g} / 1$ 圈 $0.1 \mu \mathrm{g} / \mathrm{I}=0.4 \mu \mathrm{g} / \mathrm{I}$

無処理区との有意差(LSD) : * P $<0.01$ $* * \mathrm{P}<0.001$

図4 サンショウモとオオアカウキクサに おけるBSM処理 (水耕) 20日後の 乾物重(平均値士S.E.)

図3 ハス田水路における草種別被度の変化 (2002年) と BSM濃度の消長 (2001、2002年) 